\title{
Design, Fabrication and Evaluation of Electrically-operated Groundnut Roasting Machine
}

\author{
Alao Adeyinka Idowu, Akande Olamide Abigael, Adeoye Babatunde Kazeem, \\ Owoyemi Modupe Beatrice
}

Department of Food Science and Technology, The Federal University of Technology, Akure, Nigeria

Email address:

aialao@futa.edu.ng (A. A. Idowu)

\section{To cite this article:}

Alao Adeyinka Idowu, Akande Olamide Abigael, Adeoye Babatunde Kazeem, Owoyemi Modupe Beatrice. Design, Fabrication and Evaluation of Electrically-operated Groundnut Roasting Machine. American Journal of Engineering and Technology Management. Vol. 5, No. 3, 2020, pp. 48-55. doi: 10.11648/j.ajetm.20200503.11

Received: September 24, 2019; Accepted: November 7, 2019; Published: June 8, 2020

\begin{abstract}
Groundnut is a valuable crop with an excellent source of protein that can be used to fight hunger and malnutrition especially in underdeveloped and developing countries. Products such as oil, peanut butter, soups, roasted groundnuts among others can be obtained from groundnuts However, in developing nations especially Nigeria, roasting of groundnut, a means of moisture removal and food processing, has been associated with drudgery and bad hygiene (that is, use of sand, ashes as means of heat transfer). This can be a source of physical and microbial contamination to the product. Hence, the need for development and evaluation of a peanut processor that alleviate the problems associated with the process. Design, fabrication and performance evaluation of groundnut roasting machine were carried out at the AGE Workshop, Federal University of Technology, Akure, Nigeria. The factors considered for the design were; the volume of product to be roasted, reduction of heat loss, inclusion of stirrer and stable roasting temperature. Raw groundnuts were roasted with the fabricated machine and parameters such as weight of raw groundnuts, weight of roasted groundnuts, weight of seeds damaged were used to evaluate the efficiency of the machine. The effect of sand on the roasted groundnuts was also determined through microbial analysis, free fatty acids, peroxide value, tannin, flavonoid, phytate and phenol. The average percentage losses were $16.15 \%$ and $5.89 \%$ for traditional and mechanical methods, respectively. The traditional and mechanical methods recorded an average roasting efficiency of $83.85 \%$ and $94.11 \%$, respectively. Both processing methods produced a product with considerable low moisture content. Processing time was reduced by 18 minutes when processed mechanically with significantly $(\mathrm{p}<0.05)$ lower antinutrients and reduced microbial load. Mechanical processing of groundnuts is more efficient than traditional roasting in terms of time and overall quality of the roasted groundnut.
\end{abstract}

Keywords: Groundnut, Roasting Machine, Efficiency, Processing Time, Overall Quality

\section{Introduction}

Groundnut, also called peanut; is a staple food in many developing countries. It is rich in protein, grows well in semiarid regions; like Nigeria and regarded as valuable cash crop for millions of households in these regions [4]. The 'nuts' are high in edible oil content (40-50\%) and protein $(25 \%)$, and also a good source of a variety of essential vitamins and minerals. Groundnut has contributed immensely to the development of the Nigerian economy. From 1956 to 1967, groundnut products including cake and oil accounted for about $70 \%$ of total Nigeria export earnings, making it the country's most valuable single export crop ahead of other cash crops like cotton, oil palm, cocoa and rubber [9]. Groundnut can be processed into butter, oil, cake, as well as roasted groundnut.

Roasted groundnut business in Nigeria is a very lucrative business that can contribute to the country's GDP however majority of its processors are still using crude, hygienic and time consuming methods and techniques for processing. Consumption of groundnuts as nuts and in the manufacture of peanut butter is based on the use of roasted groundnut kernels. Roasting time has a significant influence on the strength of the odour and flavour. Raw and roasted groundnuts should be free of foreign material, unadulterated with toxic or noxious substances such as pesticides and 
microorganisms. Roasting of groundnut brings about thermal changes in the chemical components at relatively high temperature. This is accomplished by either using a hot air or small metal surface to heat up the material to the required temperature at which the material changes to required colour and must be abruptly stopped using cool air to avoid food destruction [7]. This involves designing and constructing of a machine that will handle this operation more effectively than the traditional methods.

The machine after construction will enhance increase in groundnut oil/cake production, which will serve as raw material for relevant cottage industries in Nigeria. The machine is also designed to eliminate the drudgery associated with the traditional method of roasting groundnut. In Nigeria mechanical roasting machines such as cashew roaster, cowpea, cake and palm kernel seed roasters are available but the high cost and/ or inaccessibility to most people makes traditional roasting the common practice. Traditionally roasting is done using different pots such as clay pots, aluminium pot, etc. on an open fire until the peanuts are roasted [11].

Forced convection roasting is new in the sense that hot air is forced right through the product, while the product is continuously mixed and moved through the machine [13]. Electric elements are used to heat the air. The heated air is continuously re-circulated, resulting in efficient energy usage. The temperature of the heated air is controlled precisely with an adjustable electronic thermostat. A perforated rotor with a screw conveyor inside gently conveys the product in the machine while it is exposed to the hot air treatment. The rotor speed is adjustable to enable the operator find the exact optimal roasting conditions for his product. The operator can easily find the optimal temperature and time from the roasting result. When the optimal speed and temperature is set, the roasting conditions are stable, resulting in continuous precise roasting of each of the particles of the product stream. The total surface area of each of the particles in process is utilized to transfer heat, resulting in a very evenly roasted product. Also, the temperature of the hot air is accurately controlled, so particles will not be exposed to extreme hot surfaces. In fact, the maximum temperature inside the machine will not exceed the set-point of the temperature controller.

\section{Materials and Methods}

\subsection{Materials and Equipment}

Raw groundnuts and the materials used in fabricating the machine were purchased from Oba market, Akure Ondo State, Nigeria. Materials used in fabrication and roasting of groundnut are stainless, mild steel, cast iron, galvanized stainless, electric motor, fibre glass, foam, mud, electric heater, spring, thermocouple, temperature regulator, circuit box, cable, bolt and nut, shaft, revolving gear, cutting disc, electrode, thermometer, salt, and spoon and sand for traditional method.
Materials and equipment used for laboratory (chemical and microbial) analyses are distilled water, incubator (model), hot plate (model), weighing balance (model), autoclave (model), oven (model) and agars (Potato Dextrose Agar and Eosin Methylene Blue).

\subsection{Methodology}

\subsubsection{Brief Description of the Fabricated Machine}

The groundnut roasting machine has an electric heater placed below the roasting chamber with regulators to monitor and control the temperature within the system. In the roasting chamber there are four wooden spring-loaded-paddles attached to a carriage which is connected to the electric motor by a stirrer shaft which is powered electrically. Figures 1 and 2 show the isometric and exploded views of the roasting machine.

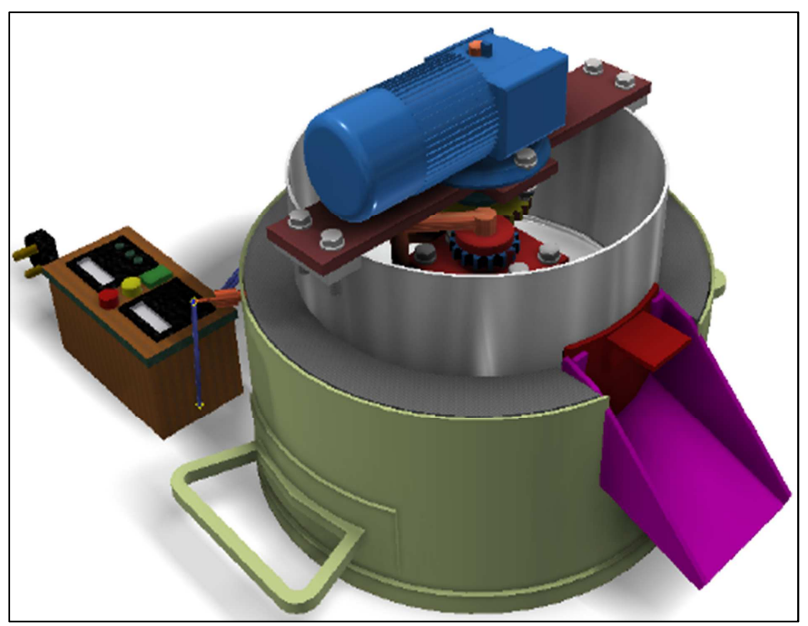

Figure 1. Isometric view.

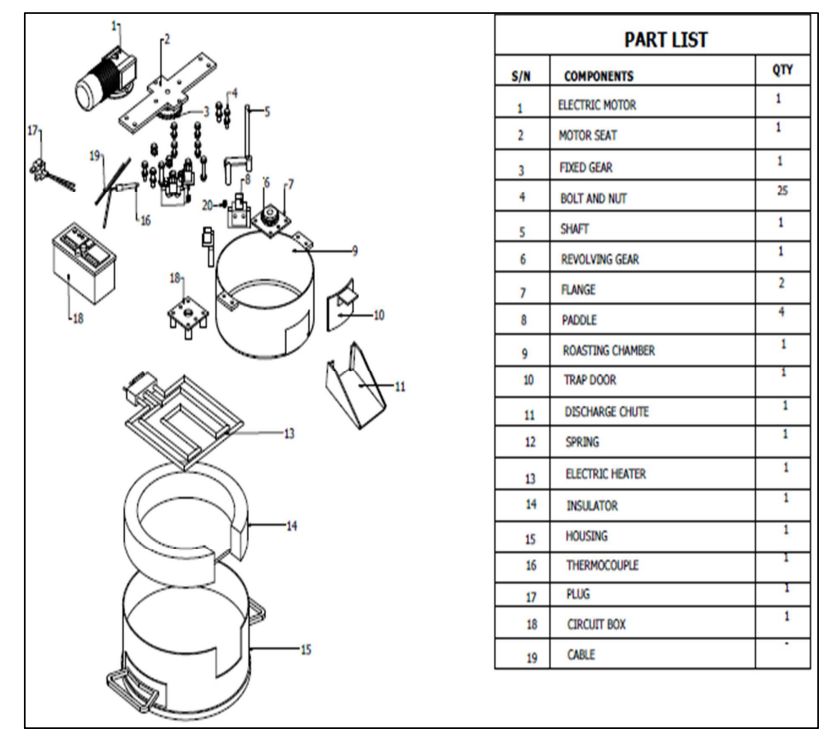

Figure 2. Exploded view.

\subsubsection{Design Analysis}

i. Determination of the volume of roasting chamber, outer chamber and lagging 
The volume of roasting chamber $\left(\mathrm{V}_{\mathrm{c}}\right)$ was determined based on $5-6 \mathrm{~kg}$ of groundnut per batch and putting into consideration $50 \%$ filling of fresh groundnut.

$$
\mathrm{V}_{\mathrm{b}}=\frac{\text { Mass of groundnut }}{\text { Bulk density of groundnut }}
$$

where $V_{b}$ is the bulk volume of the groundnut based on the mass of the groundnut to be processed given as $6 \mathrm{~kg}$ (maximum) and the true density of fresh groundnut seed is given as $619 \mathrm{~kg} / \mathrm{m}^{3}$ [15].

$$
\begin{aligned}
\mathrm{V}_{\mathrm{b}} & =\frac{6 \mathrm{~kg}}{619 \mathrm{~kg} / \mathrm{m}^{3}} \\
\mathrm{~V}_{\mathrm{b}} & =0.009693 \mathrm{~m}^{3}
\end{aligned}
$$

Required volume of roasting chamber $=0.009693 / 50 \%$

$$
\mathrm{V}_{\mathrm{C}}=0.019386 \mathrm{~m}^{3}
$$

For effective heat transfer, the groundnut mass should have a lower surface ratio to the heating surface. Thus, a larger diameter to height ratio, selecting a height range of $150.0-$ $200.0 \mathrm{~mm}$;

$$
\begin{gathered}
\mathrm{V}_{\mathrm{C}}=0.019386 \mathrm{~m}^{3}=\pi \times \mathrm{r}^{2} \times \mathrm{h} \\
\mathrm{V}_{\mathrm{C}}=0.019386 \mathrm{~m}^{3}=\pi \times \mathrm{rr}^{2} \times 0.2 \mathrm{~m} \\
\mathrm{r}=0.1756 \mathrm{~m}=18 \mathrm{~cm}
\end{gathered}
$$

The radius for the roasting chamber is given as $18 \mathrm{~cm}$.

A lagging thickness of $1 \mathrm{~cm}$ is introduced to prevent heat loss from the roasting chamber. Therefore, the volume of the outer chamber is calculated as:

$$
\begin{gathered}
\mathrm{V}_{\mathrm{O}}=\pi \times 0.19 \mathrm{~m}^{2} \times 0.2 \mathrm{~m} \\
\mathrm{~V}_{\mathrm{O}}=0.02268 \mathrm{~m}^{3}
\end{gathered}
$$

The volume of lagging is calculated as:

$$
\begin{gathered}
\mathrm{V}_{\mathrm{L}}=\pi \times\left(0.19^{2}-0.18^{2}\right) \times 0.2 \\
\mathrm{~V}_{\mathrm{L}}=0.002325 \mathrm{~m}^{3}
\end{gathered}
$$

ii. Determination of the weight and volume of paddle

The volume of paddle is determined using the method described by [25];

$$
\mathrm{V}_{\mathrm{P}}=\left(1_{\mathrm{p}} \times \mathrm{b}_{\mathrm{p}} \times \mathrm{h}_{\mathrm{p}}\right)
$$

The volume of 4 paddles is given as:

$$
\begin{gathered}
\mathrm{V}_{\mathrm{P}}=4 \times(0.08 \times 0.002 \times 0.04) \\
\mathrm{V}_{\mathrm{P}}=0.0000256 \mathrm{~m}^{3}
\end{gathered}
$$

where the paddle length is selected as $0.08 \mathrm{~m}$, paddle breadth is $0.002 \mathrm{~m}$ and the height is $0.04 \mathrm{~m}$.

The density of the wood, $\rho=0.980 \mathrm{~g} / \mathrm{cm}^{3}=980 \mathrm{~kg} / \mathrm{m}^{3}$

Total weight of paddle,

$$
\mathrm{W}_{\mathrm{P}}=\rho_{2} \times \mathrm{V} \times \mathrm{g}
$$

$$
\begin{aligned}
& =980 \mathrm{~kg} / \mathrm{m}^{3} \times 0.0000256 \mathrm{~m}^{3} \times 9.8 \mathrm{~m} / \mathrm{s}^{2} \\
& =0.246 \mathrm{~N} \\
& \text { iii. Determination of the weight of materials to be } \\
& \text { processed }
\end{aligned}
$$

The maximum weight of the material to be processed is calculated, for $6 \mathrm{~kg}$ mass of fresh groundnut.

Weight $=$ Mass $\times$ Acceleration due to gravity

$$
\begin{aligned}
& =6 \mathrm{~kg} \times 9.8 \mathrm{~m} / \mathrm{s}^{2} \\
& =58.8 \mathrm{~N}
\end{aligned}
$$

iv. Determination of the total weight of gears

The total weight of the gearing systems is the addition of the weight of the fixed gear, the revolving gear and weight of gear base;

$$
\mathrm{W}_{\mathrm{gt}}=\mathrm{W}_{\mathrm{fg}}+\mathrm{W}_{\mathrm{rg}}+\mathrm{W}_{\mathrm{gb}}
$$

where $\mathrm{W}_{\mathrm{gt}}=$ total weight of the gear system, $\mathrm{W}_{\mathrm{fg}}=$ weight of fixed gear, $\mathrm{W}_{\mathrm{rg}}=$ weight of revolving gear and $\mathrm{W}_{\mathrm{gb}}=$ weight of gear base.

Volume of fixed gear, $\mathrm{V}_{\mathrm{fg}}=\pi \times\left(0.05^{2}-0.01^{2}\right) \times 0.01=$ $0.000075398 \mathrm{~m}^{3}$

where the outer diameter of the gear is $0.05 \mathrm{~m}$, inner diameter is $0.01 \mathrm{~m}$ and the height is $0.01 \mathrm{~m}$.

Weight of fixed gear, $W_{\text {fg }}=0.000075398 \mathrm{~m}^{3} \times 7850 \mathrm{~kg} / \mathrm{m}^{3}$ $x 9.8 \mathrm{~m} / \mathrm{s}^{2}=5.8 \mathrm{~N}$

Volume of revolving gear, $\mathrm{V}_{\mathrm{rg}}=\pi \times\left(0.035^{2}-0.01^{2}\right) \mathrm{x}$ $0.025=0.000088357 \mathrm{~m}^{3}$

where the outer diameter of the gear is $0.035 \mathrm{~m}$, inner diameter is $0.01 \mathrm{~m}$ and the height of $0.025 \mathrm{~m}$,

Weight of revolving gear, $\mathrm{W}_{\mathrm{rg}}=0.000088357 \mathrm{~m}^{3} \mathrm{x}$ $7850 \mathrm{~kg} / \mathrm{m}^{3} \times 9.8 \mathrm{~m} / \mathrm{s}^{2}=6.797 \mathrm{~N}$

Volume of the gear base, $\mathrm{V}_{\mathrm{gb}}=0.1 \mathrm{~m} \times 0.1 \mathrm{~m} \times 0.005 \mathrm{~m}=$ 0.00005

Weight of gear base, $\mathrm{W}_{\mathrm{gb}}=0.00005 \mathrm{~m}^{3} \times 7850 \mathrm{~kg} / \mathrm{m}^{3} \mathrm{x}$ $9.8 \mathrm{~m} / \mathrm{s}^{2}=3.8465 \mathrm{~N}$

The total weight of the gear $=5.8 \mathrm{~N}+6.797 \mathrm{~N}+3.8465 \mathrm{~N}=$ $16.4365 \mathrm{~N}$

v. Determination of the torque on stirrer

The torque on the stirrer is calculated using the total weight of the maximum mass of groundnut that would be processed.

$$
\mathrm{T}_{\mathrm{R}}=\text { Total load } \mathrm{x} \text { radius of stirrer. }
$$

For optimal stirring of the material, the radius of the radius chamber is considered as the radius of stirrer, which is $0.18 \mathrm{~m}$

$$
\begin{gathered}
\mathrm{T}_{\mathrm{R}}=58.8 \mathrm{~N} \times 0.18 \mathrm{~m} \\
\mathrm{~T}_{\mathrm{R}}=10.584 \mathrm{Nm}
\end{gathered}
$$

vi. Determination of power required to roast groundnut

The minimum quantity of heat and power required to roast groundnut is given as:

$$
\begin{gathered}
P=\frac{Q}{t} \\
Q=m c_{p}\left(T_{1}-T_{2}\right)
\end{gathered}
$$

where, $\mathrm{P}$ is the power required; $\mathrm{Q}$ is the quantity of heat 
required to heat the groundnut $(\mathrm{KJ}) ; \mathrm{m}$ is the mass the groundnut $(\mathrm{Kg})$; $\mathrm{c}$ is the specific heat capacity $(\mathrm{KJ} / \mathrm{kg} / \mathrm{K}) ; \mathrm{T}_{1}$ is initial temperature and $T_{2}$ is the final temperature; $t$ is the time it takes to roast the groundnut. For $6 \mathrm{~kg}$ mass of groundnut and a temperature range of 30 to $95{ }^{\circ} \mathrm{C}$, the heat required is given as:

$$
\begin{gathered}
\mathrm{Q}=6 \mathrm{~kg} \times 3.5 \mathrm{KJ} / \mathrm{kg}^{\circ} \mathrm{C} \times\left(95-30{ }^{\circ} \mathrm{C}\right) \\
\mathrm{Q}=1365 \mathrm{KJ}
\end{gathered}
$$

The power, $\mathrm{P}$, required $=1365 /(15 \times 60)=1.52 \mathrm{KW}$

Therefore, power required to roast the material is $1.52 \mathrm{KW}$, and this resulted in the selection of a heating filament of 1.8 $\mathrm{KW}$ to account for factor of safety of $20 \%$. The calculation was based on using average of 15 minutes for a batch roasting.

\subsubsection{Shaft Design}

In the determination of the diameter for the stirrer, the torsional moment of the shaft is needed. The diameter of the shaft, $\left(\mathrm{d}_{\mathrm{S}}\right)$ is calculated as:

$$
d_{s}{ }^{3}=\frac{16}{\pi s_{s}} \sqrt{\left(K_{t} M_{t}\right)^{2}+\left(K_{b} M_{b}\right)^{2}}
$$

where the allowable stress, Ss is $45.0 \mathrm{MPa}=45 \times 10^{6} \mathrm{~N} / \mathrm{m}^{2}$; The combined shock and fatigue factor applied to bending moment, $\mathrm{Kb}$ and combined shock and fatigue factor applied to torsional moment, $\mathrm{Kt}$ are given as 1.5 and 1.0 respectively [17]. Therefore, maximum bending moment, $\mathrm{Mb}$ as 31.45 $\mathrm{Nm}$ and maximum torsional moment, Mt as 10.584 .

$$
\begin{gathered}
\mathrm{d}_{\mathrm{s}}{ }^{3}=\frac{16}{\pi \times 45 \times 10^{6}} \sqrt{(1.0 \times 10.584)^{2}+(1.5 \times 31.45)^{2}} \\
\mathrm{~d}_{\mathrm{s}}=0.01762 \mathrm{~m}
\end{gathered}
$$

Taking into consideration, the factor of safety of 1.2 , the diameter of the stirrer shaft $=19.38 \mathrm{~mm} \approx 20 \mathrm{~mm}$.

\subsubsection{Machine Fabrication}

The material used in fabrication of the roasting machine is stainless steel. Stainless steel was selected to prevent contamination of groundnut during roasting. The following constructional operations were carried out on the components before the machine was finally built. These are: marking out and cutting of components, drilling of components, machining of shafts, welding of components, filling and smoothing, assembling of components, and painting.

The workshop tools and machines used included: scriber, steel rule, compass, centre punch and treadle-operated guillotine for cutting and welding machine for joining. Lathe machine for turning of specific parts, grinding and cutting machine for separation of components and smoothing of surfaces.

\subsubsection{Groundnut Preparation and Roasting}

The selection of the present peanut (Arachis hypogaea) variety was based upon its high yield and productivity and popularity among local consumers. Roasting was carried using two methods, traditional and mechanical, respectively and these were compared to determine the best. About $3 \mathrm{~kg}$ of groundnut was weighed using weighing balance and was roasted using sand as medium of heat transfer and the stove as source of heat. Sharp sand was poured inside an empty pot, the sand was heated to $44{ }^{\circ} \mathrm{C}$ then the groundnut was mixed with $3.5 \mathrm{~g}$ of salt to give it sweet taste and was poured inside the hot sharp sand to subject it to roasting at $60{ }^{\circ} \mathrm{C}$.

The same sample of groundnut was roasted using the fabricated machine whereby $3 \mathrm{~kg}$ of groundnut was weighed using weighing balance and the temperature was set to be $60{ }^{\circ} \mathrm{C}$ with the help of the temperature regulator to avoid burning of the groundnut. The roasting time and weight of the groundnut were recorded for the two methods.

\subsubsection{Machine Evaluation}

The fabricated machine was evaluated by determining the weight of roasted seed damaged (over roasted), $\mathrm{Wd}$; the weight of roasted seed not damaged, $\mathrm{Wr}$; the total weight of seed roasted, $\mathrm{Wt}$; the weight of broken seeds, $\mathrm{Wb}$; and the weight of good seeds, Wg. The throughput capacity, percentage breakage, percentage losses and roasting efficiency was then calculated and used to evaluate the machine [18, 23].

The throughput capacity, Tc of the groundnut roasting machine was calculated by summing the total number of batches in kilograms divided by the total time required for the roasting.

$$
\mathrm{T}_{\mathrm{C}}=\frac{\mathrm{W}_{\mathrm{t}}}{\mathrm{t}} \%
$$

The percentage of seed losses, $\% \mathrm{~L}$ is the amount of seeds lost to excessive roasting, it is ratio of damage seed to the total seeds roasted.

$$
\% \mathrm{~L}=\frac{\mathrm{W}_{\mathrm{d}}}{\mathrm{W}_{\mathrm{t}}} \%
$$

The percentage breakage, $\% \mathrm{~B}$ is the amount of seeds broken while stirring during roasting; it is the ration of broken seeds to the total amount of seeds.

$$
\% \mathrm{~B}=\frac{\mathrm{W}_{\mathrm{b}}}{\mathrm{W}_{g}+\mathrm{W}_{\mathrm{b}}} \%
$$

The Roasting Efficiency, Er of the roasting machine was calculated based on percentage of the edible roasted groundnuts. It is the ratio of the weight of the roasted groundnut not damaged $\left(\mathrm{W}_{\mathrm{r}}\right)$ the total weight of the roasted groundnut $\left(\mathrm{W}_{\mathrm{t}}\right)$.

$$
\mathrm{ER}=\frac{\mathrm{W}_{r}}{\mathrm{~W}_{\mathrm{t}}} \%
$$

\subsubsection{Chemical Analysis of Roasted Groundnut}

\section{i. Moisture content}

Moisture content was determined according to [2]. About 5 $\mathrm{g}$ of well mixed sample was accurately weighed into a moisture dish and transferred to an air oven previously heated to temperatures of $105^{\circ} \mathrm{C}$ and drying was done for 3 hrs. The final weight of the sample was taken after the drying 
period and cooling in a dessicator. This was reported as the percent weight loss.

ii. Free fatty acid

Diethyl ether $(25 \mathrm{ml})$ was mixed with $25 \mathrm{ml}$ alcohol and 1 $\mathrm{ml}$ phenolphthalein and carefully neutralized with $0.1 \mathrm{M}$ $\mathrm{KOH}$. The sample (1.1g) was dissolved in the mixed neutral solvent and titrated with aqueous $0.1 \mathrm{M} \mathrm{KOH}$ with constant shaking until a pink colour which persisted for fifteen seconds was obtained [2].

iii. Peroxide value

About $1 \mathrm{~g}$ of the sample was weighed into a clean dry boiling tube and while still liquid, one gram of powdered potassium iodide and $20 \mathrm{ml}$ of solvent mixture (2 vol. glacial acetic acid +1 vol. chloroform) was added. The tube was placed in boiling water so that the liquid boils within 30 seconds and allowed to boil vigorously for not more than 30 seconds. The contents was quickly poured into a flask containing $20 \mathrm{ml}$ of potassium iodide (five percent). The tube was washed twice with twenty five $\mathrm{ml}$ of water and titrated with $0.002 \mathrm{M}$ sodium thiosulphate solution using starch. The blank was determined as well [2].

iv. Tannin

The procedure described by [16] was adopted for tannin analyses. About $400 \mathrm{mg}$ of the milled groundnut samples were placed into individual conical flasks and $40 \mathrm{ml}$ of diethyl ether containing $1 \%$ acetic acid $(\mathrm{v} / \mathrm{v})$ was added. The mixture was properly mixed. Each supernatant was carefully discarded after five minutes and $20 \mathrm{ml}$ of $70 \%$ aqueous acetone was added and the flasks were plugged with cotton wool covered with aluminium foil. The mixtures were placed in the electrical shaker for $2 \mathrm{~h}$ for extraction. After extraction, the flasks contents were filtered using Whatman filter paper and the resultant extract was used for analyses. Each tannin extract $(50 \mathrm{ml})$ was poured into tubes and made up to $1 \mathrm{ml}$ with distilled water. The Folin Ciocalteu reagent $(0.5 \mathrm{ml})$ was added and thoroughly mixed. Then $2.5 \mathrm{ml}$ of $20 \%$ sodium carbonate solution was added to each solution and mixed. The mixtures were then kept for $40 \mathrm{~min}$ at room temperature, after which absorbance was taken using spectrophotometer and concentration was calculated from the tannic acid standard curve.

\section{v. Phytate}

The groundnut samples were analysed for phytic acid by using the method of [16]. $100 \mathrm{ml}$ of $2 \%$ concentrated $\mathrm{HCl}$ was used to soak $2 \mathrm{~g}$ of the milled samples already weighed into $250 \mathrm{ml}$ conical flask for $3 \mathrm{~h}$. After proper extraction, the mixture was filter through filter paper. The obtained filtrate $(50 \mathrm{ml})$ was poured into $250 \mathrm{ml}$ beaker and $100 \mathrm{ml}$ of distilled water was added to it. Exactly $10 \mathrm{ml}$ of $0.3 \%$ ammonium thiocyanate solution was added into each of the solution as indicator. Each of the solution was titrated with standard iron chloride solution, which contained $0.00195 \mathrm{~g}$ iron per ml. The percentage phytic acid was then calculated.

\section{vi. Flavonoid}

The flavonoid contents of the groundnuts were determined using spectrophotometric method [21]. The sample contained $1 \mathrm{ml}$ of the extract and $1 \mathrm{ml}$ of $2 \% \mathrm{AlCl}_{3}$ solution dissolved in methanol. Samples were incubated for $1 \mathrm{~h}$ at room temperature. The absorbance were determined using Genesys 10-UV spectrophotometer (Thermo Electron Corporation) at $\lambda \max =415 \mathrm{~nm}$. The samples were prepared in triplicate for each analysis and the mean value of absorbance was obtained. The same procedure was repeated for the standard solution of rutin and the calibration line was construed. Based on the measured absorbance, the flavonoids concentration was read $(\mathrm{mg} / \mathrm{g})$ on the calibration line; then, the content of flavonoids in extracts was expressed in milligrams rutin equivalent per $g$ of the groundnut.

vii. Total phenol content

Total phenol content (TPC) of the samples was determined by the method of [24]. Briefly, phenolic extracts of groundnut $(0.2 \mathrm{ml})$ was mixed with $2.5 \mathrm{ml}$ of $10 \%$ Folin Ciocalteu's reagent and $2 \mathrm{ml}$ of $7.5 \%$ Sodium carbonate. The reaction mixture was incubated at $45^{\circ} \mathrm{C}$ for $40 \mathrm{~min}$., and the absorbance was measured at $760 \mathrm{~nm}$ in the spectrophotometer. Gallic acid was used as standard phenol.

\subsubsection{Microbial Analysis}

\section{Escherichia coli}

The 10-fold serial dilution method of [10] was used. Initial tenfold dilution of samples were performed by adding an appropriate volume of physiological saline to each sample, e.g., $10 \mathrm{ml}$ of the saline water was added to $2 \mathrm{~g}$ sample in a dilution bottle and thoroughly shaken to dislodge microorganisms. Subsequent 10-fold dilutions was carried out by adding $1 \mathrm{ml}$ of the penultimate dilution to $9 \mathrm{ml}$ of fresh diluents. Finally, $1 \mathrm{ml}$ of an appropriate dilution was placed in a petri dish, the appropriate sterilized agar (Eosin methylene blue) was poured into the petri dish, allowed to cool and solidify then incubated at $30^{\circ} \mathrm{C}$ for $24 \mathrm{hrs}$. At the end of incubation period the observable growth were counted and noted.

Aspergillus spp were determined following the same procedure as E. coli but potato dextrose agar was used and incubation was carried out at $25^{\circ} \mathrm{C}$ for $72 \mathrm{hrs}$.

\section{Results and Discussion}

\subsection{Efficiency of Roasting Method}

The comparison between the efficiency of the traditional method and mechanical method of roasting of groundnut are shown in Table 1. The efficiency of the roasting methods ranged from 84 to $87 \%$ and 92 to $93 \%$ for both traditional and mechanical methods, respectively. The increase in efficiency from the machine is as a result of the increased output of well roasted peanut from the machine, ranged from 2.70 to $2.79 \mathrm{~kg}$ compared to that of the traditional method that ranged from 2.52 to $2.60 \mathrm{~kg}$. The weight of the damaged seeds influenced the percentage loss. The traditional method has a comparatively high percentage loss $(4.33-5.67 \%)$ to uneven heat distribution that resulted into many damaged seeds during roasting. The mechanical method, unlike the traditional method, has a relatively low percentage loss (1.67 $-2.33 \%$ ) which could be as a result of an incorporated stirrer 
that evenly stir the groundnut being roasted in the machine. Also, the time employed in the mechanical roasting process was considerably low compared to that of the traditional method. Therefore, the problem of drudgery associated with traditional method was easily checkmated.

The two roasting processes recorded moisture content of about $4.51 \%$ and moisture loss of about $43 \%$. This was a bit higher than the moisture content of $3.20 \%$ reported by [14]; this could be attributed to variety and duration of roasting. The moisture loss is as a result of heat and mass transfer whereby water is driven out of groundnut by the heat applied during traditional and mechanical roasting. The lack of significant differences between the two processes show the effectiveness of the two roasting methods in reducing moisture to a satisfactory shelf stable level.

Table 1. Physical parameters showing efficiency of roasting method.

\begin{tabular}{lllll}
\hline Method of roasting & $\begin{array}{l}\text { Weight of raw } \\
\text { groundnut }(\mathbf{k g})\end{array}$ & $\begin{array}{l}\text { Weight of roasted } \\
\text { groundnut (kg) }\end{array}$ & $\begin{array}{l}\text { Weight of damaged } \\
\text { groundnut }(\mathbf{k g})\end{array}$ & $\begin{array}{l}\text { Roasting time } \\
(\mathbf{m i n u t e s})\end{array}$ \\
\hline Traditional & $3.00 \pm$ & $2.56 \pm 0.03$ & $0.17 \pm 0.02$ & $35.63 \pm 2.12$ \\
Mechanical & $3.00 \pm$ & $2.75 \pm 0.06$ & $0.06 \pm 0.01$ & $60 \pm$ \\
\hline
\end{tabular}

Table 1. Continued.

\begin{tabular}{|c|c|c|c|c|}
\hline Method of roasting & Roasting efficiency (\%) & Loss (\%) & Throughput Capacity (kg/h) & Moisture content (\%) \\
\hline Traditional & $85.22 \pm 1.10$ & $5.00 \pm 0.55$ & 0.05 & $4.51 \pm 0.19$ \\
\hline Mechanical & $91.56 \pm 1.23$ & $1.89 \pm 0.31$ & 0.05 & $4.50 \pm 0.03$ \\
\hline
\end{tabular}

\subsection{Physiochemical Properties of Groundnut Sample (FFA AND PV)}

The physiochemical properties of raw groundnut (before roasting), traditional and mechanical method are presented in Table 2. The FFA and PV of the processed groundnuts recorded a non-significant $(\mathrm{p}>0.05)$ increase and decrease respectively. The result is in agreement with that reported by [3]. That observed a decrease in peroxide value and a slight increase in free fatty acids after roasting of kernels. Peroxide value is an indication of the initial stage of fat and oil deterioration. It is an indicator to determine the amount of hydroperoxides, the primary oxidation product of oil and fat [8]. A fat that has a peroxide value greater than 10 units is considered rancid [1]. The roasted groundnut for both traditional and mechanical roasting fall within the acceptable range. The decreased PV reported after roasting is due to the fact that peroxides are not stable during heating and may start decomposing [20]. Roasting slightly increased free fatty acid, probably due to increased cell destruction and lack of enzyme inactivation.

Table 2. Free Fatty and Peroxide Value.

\begin{tabular}{lll}
\hline SAMPLES & FFA $(\%)$ & PV $(\%)$ \\
\hline Before roasting & $0.06 \pm 0.12^{\mathrm{a}}$ & $2.23 \pm 0.31^{\mathrm{a}}$ \\
Traditional roasting & $0.18 \pm 0.13^{\mathrm{a}}$ & $0.84 \pm 0.08^{\mathrm{b}}$ \\
Mechanical roasting & $0.14 \pm 0.12^{\mathrm{a}}$ & $0.84 \pm 0.08^{\mathrm{b}}$ \\
\hline
\end{tabular}

Mean \pm Standard Deviation of Mean, values with the same superscript in the same column are not significantly different ( $p$ 0.05). Keys: BR- Before Roasting, TR- Traditional Roasting, MR- Mechanical Roasting

\subsection{Antinutrients Properties of Groundnut Samples (Tannin, Phytate, Flavonoid and Phenolic Compositions)}

The effects of roasting on the tannin, phytate, flavonoid and phenolic composition (antinutrients) of peanut (Arachis hypogaea L.) is as shown in Table 3 . The groundnut were roasted at $60{ }^{\circ} \mathrm{C}$ using traditional method (i.e. using sand as a medium of heat transfer) and also were roasted at $60{ }^{\circ} \mathrm{C}$ using the fabricated roasting machine. It was observed that the two roasting methods employed significantly $(p<0.05)$ reduced the presence of the anitinutrients in the groundnut; there was more reduction of antinutrients using the mechanical method. This could be as a result of even distribution of heat within the time frame. From the results of this study, phytate content was reduced by about $61 \%$, this is in agreement with findings of [19] that reported roasting caused $60.69 \%$ reduction in phytate of Dolichos lablab bean.

Thermal processing is reported to significantly alter the phytochemical and functional composition in legumes including peanuts [22]. [5] Investigation was carrird out the effects of different processing techniques such as boiling, oil-, and dry-roasting on the phytochemical composition of groundnuts. The authors reported a decrease in flavonoids and an increase in phenolic contents of dry roasted groundnuts. The increase in phenol could be attributed to prior blanching before roasting in their study which could have released polyphenolic compound concentrated in the peanut hull.

Table 3. Total Tannin, Phytate, Flavonoid and Phenolic Content of Groundnut.

\begin{tabular}{lllll}
\hline \multirow{2}{*}{ SAMPLES } & $\begin{array}{l}\text { TANNIN } \\
(\mathbf{m g} / \mathbf{g})\end{array}$ & $\begin{array}{l}\text { PHYTATE } \\
(\mathbf{m g} / \mathbf{g})\end{array}$ & $\begin{array}{l}\text { FLAVONOID } \\
(\mathbf{m g} / \mathbf{g})\end{array}$ & $\begin{array}{l}\text { PHENOLIC } \\
(\mathbf{m g} / \mathbf{g})\end{array}$ \\
\hline $\mathrm{BR}$ & $0.22 \pm 0.01^{\mathrm{a}}$ & $33.74 \pm 0.04^{\mathrm{a}}$ & $2.90 \pm 0.06^{\mathrm{a}}$ & $2.86 \pm 0.04^{\mathrm{a}}$ \\
$\mathrm{TR}$ & $0.16 \pm 0.02^{\mathrm{b}}$ & $20.62 \pm 0.02^{\mathrm{b}}$ & $2.63 \pm 0.02^{\mathrm{b}}$ & $2.48 \pm 0.08^{\mathrm{b}}$ \\
MR & $0.11 \pm 0.01^{\mathrm{c}}$ & $20.22 \pm 0.02^{\mathrm{c}}$ & $2.22 \pm 0.03^{\mathrm{c}}$ & $2.29 \pm 0.10^{\mathrm{c}}$ \\
\hline
\end{tabular}

Mean \pm Standard Deviation of Mean, values with the same superscript in the same column are not significantly different

Legend

BR- Before Roasting

TR- Traditional Roasting

MR- Mechanical Roasting 


\subsection{Microbial Load of Groundnut Sample}

The microbial analyses of the groundnut before and after roasting is as shown in Table 4. Escherichia coli are bacteria found in the environment, intestines of people and animal. E.coli are a large and diverse group of bacteria. They are used as indicator organisms for food. Its presence in foods indicate faecal contamination of the foods and likely presence of other microorganisms. The groundnuts were devoid of Escherichia coli which is in agreement with the study of [6]. According to [12], Aspergillus spp such as Aspergillus flavus is a mycotoxigenic fungus that possesses the ability to produce Baflatoxins. It is the most widely reported food-borne fungus and is one of the dominant species found on stored products, particularly grains. The results revealed the absence of Aspergillus flavus on the roasted groundnut.

Table 4. Microbial load (Aspergillus spp and E-coli).

\begin{tabular}{lll}
\hline Sample & Aspergillus spp & Escherichia coli \\
\hline BR & $3.0 \times 10^{3}$ & Nil \\
TR & Nil & Nil \\
MR & Nil & Nil \\
\hline
\end{tabular}

BR: Before Roasting

TR: Traditional Roasting

MR: Mechanical Roasting

\section{Conclusion}

The machine was developed with a suitable heating medium, temperature regulator and stirrer for effective heat distribution. The automatic stirrer rotates at $140 \mathrm{rpm}$, thereby reducing drudgery. The roasting efficiency of the machine was higher than that of the traditional method. The performance test has shown that the use of developed roasting machine had provided hygienic and better roasted food items than the traditional method of roasting.

\section{References}

[1] Allen, J. C. and Hamilton, R. J. (1994). Rancidity in Foods 3rd edition; Blackie Academic and Professional, Glasgow.

[2] AOAC (2012) Official Method of Analysis: Association of Analytical Chemists. 19th Edition, Washington DC, 121-130.

[3] Bai, S. H., Darby, I, Nevenimo, T., Hannet, G., Hannet, D., Poienou, M., Grant, E., Brooks, P., Walton, D., Randall, B., Wallace, H. M. (2017). Effects of roasting on kernel peroxide value, free fatty acid, fatty acid composition and crude protein $\begin{array}{lllll}\text { content. } & P L O S \quad O N E, & 12 & \text { (9): } 0184279 .\end{array}$ https://doi.org/10.1371/journal.pone.0184279

[4] CGIAR (2004). Encyclopedia of Agricultural Science. Technical advisory committee, Priorites and Strategies for resources allocation during (1998-2000): In CGIAR Financial Report 2004 (English), Washington, DC: World Bank. http://documents.worldbank.org/curated/en/317861468314730 882/CGIAR-Financial-Report-2004

[5] Chukwumah, Y., Walker, L., Vogler, B. and Verghese, M., (2007). Effects of Roasting on Kernel Peroxide Value, Free
Fatty acid, Fatty Acid Composition and Crude Protein content. Journal of Agriculture and Food Chemistry; 55: 9266 - 9273. DOI: 10.1371/journal.pone.0184279.

[6] Eglezos, S., Huang, B and Stuttard, E. (2007). A Survey of the Bacteriological Quality of Preroasted Peanut, Almond, Cashew, Hazelnut, and Brazil Nut Kernels Received into Three Australian Nut-Processing Facilities over a Period of 3 Years. Journal of Food Protection, 71 (2): 402-404.

[7] Gell, H. A. and Porto, B. (1996). Removal Coffee Roaster Oven Chamber: United State Patent US5500237.

[8] Gotoh, N and Wada, S. (2006). The Importance of Peroxide Value in Assessing Food Quality and Food Safety. Journal of the American Oil Chemists; 83 (5): 473-474.

[9] Harkness, C. K., Kolawale, B. and Yayock, J. Y. (1976). Groundnut Research in Nigeria. Samaru Conference Paper.

[10] Harrigan, W. F. and McCance, M. E. (1990). Laboratory Methods in Food and Dairy Microbiology, 8th edition; Academic Press, London.

[11] Ihekoronye, A. I. and Ngoddy, P. O. (1985). Integrated Food Science and Technology for the Tropics. Macmillan Education Ltd. London.

[12] Jackson, S. A. and Dobson, A. D. W. (2016). Yeasts and Molds: Aspergillus flavus. Reference Module in Food Science. https://doi.org/10.1016/B978-0-08-100596-5.01086-6

[13] Kabri, H. U. Ankidawa, B. A. and Elson, J. (2006). Modification and Performance Evaluation of a Manually Operated Drum Groundnut Roaster. Savannah Journal of Agriculture, 1 (2): 88-93.

[14] Mada, S. B., Garba, A., Mohammed, A., Mohammed, A., Olagunju, A., Mohammed, H. A. (2012). Effects of Boiling and Roasting on Antinutrients and Proximate Composition of Local and Some Selected Improved Varieties of Arachis hypogea I. (Groundnut), 1 (1): 45-53.

[15] Maduako, J. N. and Hamman, M. (2004). Determination of some Physical Properties of three Groundnut Varieties. Nigerian Journal of Technology, 24 (2): 159-280.

[16] Makkar, H. P. S., Bluemmel, M., Borowy, N. K. and Becker, K. (1993). Gravimetric Determination of Tannins and their Correlations with Chemical and Protein Precipitation Methods. Journal of Science, Food and Agriculture; 61: 161-165.

[17] Okunola, A. (2016). Nigeria: Positioning Rural Economy for Implementation of Sustainable Development Goals. Turkish Journal of Agriculture, Food Science and Technology; 4: 752757. 10.24925/turjaf.v4i9.752-757.858.

[18] Olaniyan, A. M., Karim, O. R., and Eromosele, E. O., (2017). Design and Development a Smallscale Peanut Roaster, The Journal of the Association of Professional Engineers of Trinidad and Tobago, 45 (2): 34-39.

[19] Osman, A. M. (2007). Effect of different processing methods on nutrient composition, anti-nutritional factors and in vitro protein digestibility on Dolichos lablab bean (Lablab purpureus (L) Sweet). Pakistan Journal of Nutrition, 6 (4): 299-303.

[20] Ozdemir, M., Ackurt, F., Yildiz, M., Biringen, G., Gurcan, T. and Loker, M. (2001). Effect of Roasting on some Nutrients of Hazelnuts (Corylus Avellena L.). Food Chemistry, 73: 185-190. 
[21] Quettier-Deleu, C., Gressier, B., Vasseur, J., Dine, T., Brunet, C., Luyckx, M., Cazin, M., Cazin, J. C., Bailleul, F. and Trotin, F. (2000). Phenolic Compounds and Antioxidant Activities of Buckwheat (Fagopyrum esculentum M.) Hulls and Flour. Journal of Ethnopharmacology; 72 (1-2): 35-42.

[22] Randhir, R., Kwon, Y-I. and Shetty, K. (2008). Effect of Thermal Processing on Phenolics, Antioxidant Activity and Health-relevant Functionality of Select Grain Sprouts and Seedlings. Innovative Food Science and Emerging Technologies; 9: 355-364. 10.1016/j.ifset.2007.10.004.

[23] Shehu, A. A., Balami, A. A., Osunde, Z. O. and Ademoh, N. A. (2017). Design and Fabrication of Shea Nut Steam Roaster.
International Journal of Scientific Research Engineering and Technology ISSN 2278 - 0882, 6 (11): 1113-1121.

[24] Singleton, V. L., Orthofer, R. and Lamuela-Raventos, R. M. (1999). Analysis of Total Phenols and other Oxidation Substrates and Antioxidants by means of Folin-Ciocalteu Reagent. Methods Enzymol.; 299: 152-178.

[25] Ugwuoke, I. C., Okegbile, O. J., Ikechukwu, I. B. and Robert T. J., (2014). Design and Development of Manually Operated Roasted Groundnut Seeds Peeling Machine, International Journal of Recent Development in Engineering and Technology, ISSN 2347-6435 (Online) 2 (4): 30-33. 